\title{
FENOMENA PROSES PENGAMBILAN KEPUTUSAN MENJADI LESBI DI KIARACONDONG BANDUNG
}

\author{
Metha Dwi Tamara \\ Jurusan Kesehatan Masyarakat STIKes Dharma Husada Bandung \\ metha.stikesdhb@gmail.com
}

\begin{abstract}
Indonesia is a country that still holds the principle of heterosexual relations even though many countries have legalized same-sex marriage. In West Java, there are many lesbian groups. Social institutions indicate that there are at least 185 lesbians in Bandung who are members of 14 small groups of 10-20 people. This research is a descriptive ethnographic study using qualitative data. To obtain qualitative data, researchers prioritize data collection techniques in the form of in-depth interviews, to dig deep information from informants. Family and environmental factors greatly influence an individual's sexual orientation. Conflicts that occur in the family that involve disappointment with the figure of a father coupled with disappointment with the opposite sex become an amplifier for individuals to change their sexual orientation into lesbians. The role of the family and surrounding environment that needs to be improved in paying attention to their children's relationships.
\end{abstract}

Keywords: Phenomenon, Self Identity, Lesbi

\section{PENDAhUluAN}

Lesbian merupakan kelainan yang disebut orientasi seksual. Terdapat tiga jenis orientasi seksual, yaitu heteroseksual yang tertarik pada jenis kelamin yang berbeda. Kedua, homoseksual yaitu individu yang tertarik dengan jenis kelamin yang sama, lakilaki yang tertarik pada laki-laki disebut gay dan perempuan yang tertarik pada perempuan disebut lesbian. Ketiga, biseksual yaitu orientasi seksual individu yang dapat tertarik pada lawan jenis kelamin dan sesama jenis kelamin. Orientasi seksual adalah sejauh mana seseorang secara erotis tertarik terhadap anggota dari jenis kelamin yang sama ataupun yang berlawanan dengan dirinya (Halgin \& Susan, 2010).
Semakin tahun semakin meningkatnya jumlah wanita lesbian, semakin banyaknya kaum lesbian ini tersebar diseluruh kota. Tetapi dikota-kota besar ataupun di media massa wanita lesbian ini dapat leluasa mengekspos diri atau memperlihatkan diri mereka sesungguhnya dan membentuk aliansi-aliansi di masyarakat.

Identitas pada lesbian tidak muncul begitu saja, tetapi identitas tersebut muncul melalui tahap-tahap perkembangan homoseksual seperti berbagai macam negosiasi hingga mencapai kesepakatan tertentu baik bersifat umum maupun khusus (Mudayat, dalam Kusuma 2014). Dalam Teori The Cass Model (Kusuma, 2014), telah 
JURNAL SEHAT MASADA VOLUME XIII NOMOR 2 Juli 2019 ISSN : 1979-2344

dijelaskan bahwa terdapat 6 proses perkembangan lesbian dan gay seperti identity confusion (kebingungan identitas), identity comparison (perbandingan identitas), identity tolerance (toleransi identitas), identity acceptance (penerimaan identitas), identity pride (kebanggaan identitas),dan identity syntesis (penerimaan identitas seutuhnya).

Menurut Tan (Budiarty, 2011) menilai penyebab lesbian dari beberapa segi kehidupan antara lain adalah (a) Pengaruh keadaan keluarga dan kondisi hubungan orang tua seperti contoh hubungan antara ayah dan ibu yang sering cekcok. Antara orang tua dan dengan anak-anak yang tidak harmonis atau bermasalah. Absennya hubungan ayah dan renggangnya hubungan antara anak dengan ayahnya yang sering dianggap menjadi penyebab anak menjadi homoseksual. Tetapi asumsi tersebut belum terbukti. Menurut Soetjiningsih (Sumadi, Suriadi \& Kirana, 2013) Broken home diduga bisa menjadi pencetus pembentukan pribadi penyimpangan seksual lesbian tersebut. (b) Pengalaman keksual buruk pada masa kanakkanak seperti pelecehan seksual atau kekerasan seksual. (c) Pengaruh lingkungan memiliki pengaruh yang sangat besar bagi seseorang untuk berkembang.

Data yang ada di LSM menunjukkan bahwa sedikitnya terdapat 185 lesbian di Bandung yang tergabung dalam 14 kelompok-kelompok kecil beranggotakan 1020 orang. Kelompok-kelompok ini tidak melulu aktif dalam dunia pergerakan, namun Jurnal Penelitian Kesehatan STIKes Dharma Husada Bandung juga kelompok-kelompok yang disatukan oleh minat. Sebagian besar berkumpul secara rutin di ruang publik dan meski masih banyak yang tidak visible di permukaan namun beberapa diantaranya masih terbuka. (Gaya Nusantara, $2013: 06$ )

Dari data tersebut dapat dilihat bahwa kaum lesbi telah menunjukkan identitas dirinya dan mencoba berinteraksi dengan masyarakat dengan membentuk komunitaskomunitas lesbi yang ada di Bandung. Kaum lesbi di Bandung mempunyai cara tersendiri untuk menunjukkan simbol-simbol ke masyarakat yang menunjukkan bahwa mereka merupakan seorang lesbi. Simbol simbol yang digunakan para lesbi untuk dimana mereka menunjukkan interkasi bahwa mereka adalah seorang lesbi tentunya dengan cara yang berbeda-beda. Dimana simbol yang diberikan lesbi tersebut belum tentu sama terhadap simbol apa yang dipahami oleh masyarakat atau perempuan normal. Cara berbicara, tindakan, atau sesuatu yang dinilai berbeda dari kaum lesbi tersebutlah yang dikategorikan sebagai simbol. Dimana simbol-simbol tersebut mempunyai makna yang berbeda sehingga dapat memunculkan pemahaman bahwa mereka berbeda dari perempuan atau menyukai sesama jenis yaitu lesbi.

Hasil penelitian Irawan (2014) menyatakan bahwa aktivitas yang melatarbelakangi lesbi antara lain adalah hubungan dengan ayah yang renggang karena mengalami perceraian orang tua hal tersebut sejalan dengan pernyataan beiber (dalam Irawan, 2014) yang 
menyatakan bahwa kurangnya kasih sayang dari seorang ayah akan menyebabkan anak mencari kasih sayang dari orang lain. Kedua adalah faktor lingkungan yang melatarbelakangi seseorang menjadi lesbian hal tersebut sejalan dengan pernyataan Kerthbeny \& Karl (dalam Irawan 2014) yang menyatakan bahwa homoseksual bukan dibawa sejak lahir, namun terbina melalui pengalaman. Ketiga adalah pelecehan seksual hingga pengalaman berhubungan dengan sesama jenis hal tersebut sejalan dengan pernytaan yang dinyataakan oleh Keith \& Karl (Irawan, 2014) yang menyatakan bahwa individu merasakan pengalaman lesbian pertama terbuka yang akan menyebabkan individu melanjutkan aktivitas seksualnya.

Berdasarkan latar belakang tersebut maka peneliti perlu untuk mengkaji permasalahan yang terjadi pada wanita lesbi dengan judul "Fenomena Proses Pengambilan Keputusan Menjadi Lesbi".

\section{METODE PENELITIAN}

Metode yang akan digunakan untuk mengumpulkan data dalam penelitian ini adalah observasi dan wawancara. Proses analisis data dalam penelitian kualitatif dimulai dengan menelaah seluruh data yang tersedia dari berbagai sumber yaitu wawancara, observasi yang telah dituliskan dalam catatan lapangan, dokumen pribadi, dan dokumen resmi.

Teknik sampling yang digunakan dalam penelitian ini adalah purposive sampling. Jumlah subjek penelitian adalah 3 orang untuk key informant. Hal ini karena subyek dibatasi pada mereka yang memiliki identifikasi yang sesuai dengan pokok permasalahan yang akan diteliti. Penelitian ini merupakan suatu penelitian etnografi yang bersifat deskriptif dengan menggunakan data kualitatif. Untuk mendapatkan data kualitatif, peneliti lebih mengutamakan teknik pengumpulan data berupa wawancara mendalam, untuk menggali informasi sedalam-dalamnya dari para informan.

Sehubungan dengan penelitian ini maka data-data yang sudah terkumpul melalui observasi, wawancara, dokumentasi maupun catatan lapangan diurutkan dan di organisasikan dalam kategori atau pokokpokok bahasan yang untuk selanjutnya diusulkan dan diuraikan sedemikian rupa kemudian dikaitkan dengan teori yang ada. Dalam hal ini, peneliti menggunakan analisa domain. Analisis domain merupakan analisa yang mempunyai tujuan untuk mengidentifikasikan kategori-kategori pemikiran yang asli serta memperoleh pandangan awal suatu budaya yang sedang diamati.

\section{HASIL DAN PEMBAHASAN}

\section{Hasil}

\section{Deskripsi partisipan 1}

Informan pertama yaitu L (23 tahun memandang wanita sebagai sosok mandiri dan dewasa sehingga L lebih fokus untuk dekat dengan perempuan dibandingkan dengan lakilaki. L juga mengaku bahwa L dulu sempat 
JURNAL SEHAT MASADA VOLUME XIII NOMOR 2 Juli 2019 ISSN : 1979-2344

mempunyai kekasih laki-laki, namum pasangannya cenderung kasar, sehingga pada akhirnya L tidak mempunyai perasaan yang klik lagi dengan laki-laki. L mulai mengenal kehidupan lesbi dari teman saat SMU, pada saat berumur 17 tahun. kemudian L masuk dalam komunitas anime atau animasi dan ada kesamaan atau hobby yang sama dengan teman dari L yang akhirnya mendapatkan suatu kecocokan dengan teman tersebut. Setelah masuk dalam kehidupan lesbi dan menjadi seorang lesbi L merasa nyaman dengan kehidupannya tersebut.

\section{Deskripsi partisipan 2}

Informan I memiliki alasan mengambil keputusan menjadi lesbi karena sejak kecil I ini menyukai sesama jenis karena I mempunyai pandangan bahwa bapaknya galak dan sering memarahi ibu I serta memukul ibu walaupun ibu I ini hanya melakukan sedikit kesalahan, selain itu I juga berfikir bahwa I ingin bapaknya meninggal untuk mengakiri penderitaan yang selama ini dilihat. Sejak saat itu I ini memiliki rasa benci terhadap laki-laki.

\section{Deskripsi Partisipan 3}

Informan R memiliki alasan menjadi lesbi karena lebih nyaman berpasangan dengan perempuan dan tidak ada hal yang dipertimbangkan untuk mengambil keputusan menjadi lesbi karena I suka dengan perempuan sejak kecil dan tomboy sejak kecil. Informan R lebih suka dengan perempuan dibandingkan laki-laki karena informan $\mathrm{R}$ lebih nyaman menjadi laki-laki. Seiring berjalannya waktu infroman ketiga menjadi diri sendiri dengan gaya yang tomboy seperti laki-laki hingga Jurnal Penelitian Kesehatan STIKes Dharma Husada Bandung suatu saat bertemu dengan perempuan yang lesbi dan kenal dengan sebuah komunitas lesbi.

\section{Pembahasan}

Dari ketiga informan lesbi yang diteliti, terdapat perbedaan alasan dalam mengambil keputusan menjadi lesbi. Seperti yang terjadi pada informan $\mathrm{L}$ cara mengidentifikasi keputusan yang akan dibuat dan alasan untuk menjadi lesbi adalah L lebih memfokuskan diri kepada perempuan dibandingkan dengan lakilaki karena L tidak mempunyai perasaan yang lebih kepada laki-laki melainkan hanya mempunyai perasaan kepada perempuan semenjak L mengalami tindak kekerasan dari pasangan heteroseksualnya dan L memandang perempuan sebagai sosok yang mandiri dan dewasa. Hal tersebut diatas sesuai dengan pendapat Kartono (Irawan, 2016) menjelaskan bahwa penyebab munculnya homoseksual terjadi karena hubungan antar manusia yang tidak serasi sehingga mereka tidak dekat dengan lawan jenis melainkan lebih dekat dengan sesama jenis. Hal tersebut juga selaras dengan pendapat Soetjiningsih (2004) yang menyatakan bahwa faktor lesbian yang dialami oleh informan M merupakan faktor lesbian yang berawal dari tanda-tanda psikologik dimana pengaruh lingkungan yang tidak baik dan tidak menguntungkan bagi kematangan seksuil yang normal ( Kartono, 2007).

Informan I mempunyai alasan menjadi lesbi karena pengalaman dari masalalu I dan perasaan benci kepada laki-laki karena awalnya I membenci sosok ayah I yang menurut I ayah I galak dan kasar. Sejak kecil I 
lesbi dan ketika SMP I mengenal seorang wanita dan beranggapan bahwa beranggapan bahwa wanita itu lembut dan tidak kasar.Hal tersebut diatas sesuai dengan pendapat yang dikemukakan oleh Soejtiningsih (2004) yang menyatakan bahwa faktor lesbian berasal dari faktor psikososial dimana homoseksual dapat terjadi karena faktor trauma kehidupan.Lesbianisme dapat terjadi karena adanya dendam, tidak suka, takut atau tidak percaya terhadap laki-laki.

Informan $\mathrm{R}$ mempunyai alasan tersendiri dalam mengambil keputusan menjadi lesbi, awalnya R sudah menyukai sesama jenis dari kecil dan perilaku $\mathrm{R}$ sejak kecil sudah seperti laki-laki, tetapi menurut informan sekunder dari R yaitu S, R lesbi karena perceraian orang tua. Hal tersebut diatas sesuai dengan pendapat Freud (dalam Soetjiningsih, 2004) yang menyatakan bahwa individu juga dapat terfiksasi pada fase homoseksual jika mengalami hal-hal tertentu didalam kehidupan seseorang.Hubungan dengan orang tua yang over protektif, lemah ataupun bermusuhan dapat menyebabkan rasa bersalah dan kecemasan yang mendorong mereka menjadi homoseksual (Beiber \& Socratides dalam Soetjiningsih, 2004). Lesbian yang dialami oleh $\mathrm{R}$ termasuk juga dalam faktor biologik yang menyebabkan terjadinya lesbian dimana faktor genetik dan hormonal dapat menyebabkan terjadinya lesbian.Begipula dengan $\mathrm{R}$ yang tomboy sejak kecil merupakan faktor hormonal.

Ketiga informan mengenal dan masuk dalam kehidupan lesbi melalui sebuah Jurnal Penelitian Kesehatan STIKes Dharma Husada Bandung komunitas lesbi. Setelah masuk dalam kehidupan lesbi ketiga informan tidak mengalami kesulitan ketika bergaul dengan lingkungan walaupun lingkungan beranggapan nergatif tentang kehidupan lesbi namun ketiga informancenderung cuek dan fokus dengan dirinya sendiri.Hal tersebut diatas sesuai dengan pendapat Engel,Blackwell dan Miniard (1994) yang menyatakan bahwa sikap merupakan pernyataan evaluatif terhadap objek, orang atau peristiwa. Hal ini mencerminkan perasaan seseorang terhadap sesuatu. Perasaan ketiga informanterhadap konsekuensi negatif yang terjadi yaitu cuek dan tidak memperdulikan perkataan seseorang.

Ketiga informan juga tidak memiliki pertimbangan apapun untuk berhenti menjadi lesbi melainkan tetap menjalani kehidupan yang dijalani oleh ketiga informanyaitu menjadi seorang lesbi dan ingin tetap menjalani kehidupan lesbi yang sekarang.Hal tersebut selaras dengan pendapat yang dikemukakan oleh Soetjiningsih (2004) yang berpendapat bahwa seorang homoseksual sintonik adalah seorang homoseksual yang tidak merasa terganggu oleh orientasi seksualnya serta tidak ada desakan, dorongan ataupun keinginan untuk merubah orientasi seksualnya.

Untuk saat ini Informan L yakin dengan pilihannya menjadi lesbi dan ingin menikmati kehidupan bersama pasangannya dikarenakan pernah disakiti oleh pasangan heterogennya. Hal tersebut sesuai dengan pendapat Soetjiningsih (2004) yang menyatakan bahwa pada tahap komitmen seorang lesbi menyadari 
JURNAL SEHAT MASADA VOLUME XIII NOMOR 2 Juli 2019 ISSN : 1979-2344

dan menerima identitas dirinya sebagai homoseksual. Informan I dalam menentukan pilihan menjadi lesbi informan I informan tidak merasa mengambil keputusan karena informan merasa menjalani kehidupan yang karena sejak awal informan sudah menjadi lesbi. Hal tersebut sesuai dengan pendapat yang dikemukakan oleh Foucault (Kusuma, 2014) yang menyatakan bahwa setiap orang dilahirkan sebagai biseksual akan menjadi apa dia nanti tergantung pada pendidikan seksual yang dilakukan dilingkungannya. Dalam arti apakah akan menjadi homoseksual, biseksual atau heteroseksual.Sedangkan informan $\mathrm{R}$ memilih untuk tetap menjadi lesbi untuk saat ini hingga selamanya. Hal tersebut selaras dengan pendapat yang dikemukakan oleh Soetjiningsih (2004) yang berpendapat bahwa Tahap perkembangan GLB (Gay, Lesbi dan Biseksual) pada tahapan komitmen pada saat itu remaja GLB mendapat kepuasan dan tidak mau merubah anggota identitas seksualnya.

Faktor keluarga dan lingkungan sangat mempengaruhi orientasi seksual individu. Konflik yang terjadi didalam keluarga yang melibatkan kekecewaan terhadap sosok seorang ayah ditambah dengan kekecewaan terhadap lawan jenis menjadi penguat bagi individu untuk merubah orientasi seksualnya menjadi lesbian. Hal ini juga sejalan dengan yang dikemukakan oleh Kartono (2006) pengaruh yang justru negatif merugikan dari pribadi ayah anak gadis itu jika sang ayah membuat kecewa sang anak gadisnya, atau ayah itu tidak berhasil memuaskan hati anak perawannya, maka peristiwa ini akan Jurnal Penelitian Kesehatan STIKes Dharma Husada Bandung memperkuat relasi antara anak gadis yang bersangkutan dengan ibunya. Jika relasi tersebut ekstrim buruk atau jahat sifatnya, maka bisa menimbulkan unsur-unsur homoseksualitas wanita atau lesbianisme. Dalam hal ini, rasa-rasa yang kontradiktif satu sama lain, yaitu perasaan kebencian dan rasa cinta anak gadis terhadap ibunya tidak bisa bisa dilepaskan dari daya tarik medan magnet ibunya, sedangkan lingkungan yang didominasi oleh perempuan lesbian dapat mendorong individu ikut tertarik dalam hubungan sesama jenis. Perilaku yang ditunjukkan bisa berupa mulai mencari tau lebih tentang lesbian baik melalui media sosial ataupun secara langsung menjalin kedekatan dengan wanita-wanita lesbian.

Bermacam-macam teori untuk menjelaskan lesbian secara garis besar salah satunya adalah teori psikososial menurut Soetjiningsih (Rohmi, 2007) dimana tandatanda psikologik yaitu perilaku kanak-kanak terutama dalam hal bermain dan berpakaian juga dianggap dapat menentukan homoseksualitas di kemudian hari. Anak lakilaki yang bermain boneka, memakai baju ibu, atau tidak menyukai permainan laki-laki disebut sissy dan jika perempuan tidak menyukai permainan perempuan dan senang bermain dengan teman laki-laki disebut tomboy.

Individu yang suka bergaul dengan teman laki-laki dan melihat laki-laki seperti melihat dirinya sendiri. Pilihan menjadi butchy karena sejak kecil sudah memiliki daya tarik terhadap wanita. Berpenampilan selayaknya laki-laki 
JURNAL SEHAT MASADA VOLUME XIII NOMOR 2 Juli 2019 ISSN : 1979-2344

dan merasa tidak nyaman jika dipaksa untuk berpenampilan seperti wanita. Menurut Agustine (Niko, 2012) lesbian juga menyatakan hal yang serupa yaitu butch khususnya yang di klasifikasikan sebagai stone butch sering di gambarkan lebih maskulin dalam cara berpakaian maupun potongan rambutnya, terkadang membebat dadanya agar lebih rata dan menggunakan sesuatu didalam pakaian dalamnya sehingga menciptakan kesan laki- laki sesungguhnya.

Jika pasangan lesbian individu tersebut mampu memenuhi kebutuhan kasih sayang ataupun kenyamanan dalam diri individu tersebut, terpenuhinya kebutuhan kasih sayang dari pasangan sejenis melahirkan rasa aman dan ketergatungan, hal ini menguatkan keberadaannya di komunitas, meskipun mungkin saja tidak sepenuhnya suka dengan sejenis.

Pilihan peran atau label dalam lesbian didukung oleh pikiran individu tentang gambaran ideal dirinya. Individu yang memilih menjadi Butchy akan berpenampilan seperti laki-laki sedangkan yang memilih menjadi Femme akan tetap seperti perempuan pada umumnya namun memiliki orientasi seksual yang berbeda. Faktor lingkungan dan keluarga juga dapat mempengaruhi individu. Konflik yang terjadi didalam keluarga yang melibatkan sosok ayah akan memberikan tambahan nilai negatif individu terhadap sosok lelaki. Sedangkan lingkungan yang didominasi oleh lesbian akan mempengaruhi individu untuk ikut terbawa dalam menjalin hubungan sesama jenis. Akan tetapi lingkungan yang mampu Jurnal Penelitian Kesehatan STIKes Dharma Husada Bandung memberikan dukungan dan kontrol bagi individu yang sudah menjadi lesbian, dapat memberikan dorongan pada diri individu untuk kembali pada orientasi seksual semestinya yaitu heteroseksual. Jika kontrol yang diberikan lemah, maka individu tidak mendapatkan dorongan untuk kembali menjadi heteroseksual. Oleh sebab itu, peran orang diekitar wanita lesbian sangatlah penting.

\section{KESIMPULAN DAN SARAN}

\section{Kesimpulan}

Hasil penelitian dapat disimpulkan bahwa dari ketiga informan lesbi yang telah diteliti ditemukan bahwa adanya faktor biologik, psikologik dan psikososial yang menyebabkan informan mengambil keputusan menjadi lesbi. Pada informan L alasan menjadi lesbi karena adanya faktor psikologik dan trauma akan pasangan heterogennya di masa lalu, pada informan I adanya faktor psikososial yang mempengaruhi informan menjadi lesbi dan pada informan $\mathrm{R}$ adanya faktor biogenik yang mempengaruhi informan menjadi lesbi. Ketiga informan lesbi mengumpulkan informasi tentang kehidupan lesbi dengan cara masuk dalam komunitas lesbi melalui teman sesama lesbi.

Setelah ketiga informan masuk dalam komunitas, ketiga informan merasa nyaman berhubungan dengan sesama perempuan, sehingga ketiga informan tidak memperdulikan pendapat negatif orang lain. Ketiga informan tidak memiliki pertimbangan apapun dalam memilih untuk berhenti menjadi lesbi, melainkan tetap 
menjalani kehidupan lesbi yang saat ini dijalani oleh ketiga informan dan lebih memiliki perasaan yang nyaman kepada pasangan masing-masing saat ini.Untuk saat ini ketiga informan lebih memilih untuk menjadi lesbi dan lebih memilih untuk menjalani kehidupan bersama dengan pasangannya tersebut.

\section{Saran}

1. Perlu diberikannya pendidikan seks untuk menghindari risiko-risiko yang berdampak buruk pada pasangan lesbian dan gay.

2. Perlu diberikan sarana yang positif dalam memberikan penyaluran dorongan biologis melalui ekspresi psikologis dan penyaluran fisik yang sehat seperti olahraga, kegiatan untuk mencintai alam, kegiatan kreativitas dan pengembangan potensi dan bakat.

3. Peran Lingkungan keluarga dan sekitar yang perlu di tingkatkan dalam memperhatikan pergaulan anaknya.

\section{DAFTAR PUSTAKA}

1. Al-Qur'an, surat Huud ayat 77-78.

2. Basyaib, F. (2006).Teori Pembuatan Keputusan. Jakarta : Penerbit Grasindo Crew, D., \& Crawford, M. (2015). Expolring the Role being of Being Out a Queer

3. Boellstorff, Tom. (2005). The Gay Archipelago (Seksualitas dan Bangsa di Indonesia). New Jersey: Princceton University Press.

4. Budiarty, A. (2011). Gaya hidup lesbian (Studi kasus di kota Makassar). (Skripsi). Makassar: Universitas Hasanuddin. Makasar

5. Cass, V. C. (1979). Homosexual identity formation: A theoretical model.
6. Craib, Ian. (1992). Teori-Teori Sosial Modern. Jakarta: Bumi Aksara. Crawford. (2000). Pengertian Lesbianisme. Jakarta: Bumi Aksara.

7. Davidson, C. G., Neale, J. M., Kring, A. M. (2010). Psikologi abnormal jilid 2, edisi sembilan. Terjemahan oleh Noermala Sari Fajar. Jakarta: Rajawali Press.

8. Davion, Gerald C., Neale, John M., \& Kring, ANN M. (2006). Psikologi Abnormal. Jakarta: PT RajaGrafindo Persada.

9. Demartoto. (2013). Seks, Gender, dan Seksualitas Lesbian. Solo: Universitas Negeri Surakarta

10. Desmita.(2008). Psikologi Perkembangan. Bandung : Penerbit Remaja Rosdakarya

11. Durand, V Mark., \& Barlow, David H. (2007). Intisari Psikologi Abnormal. edisi kelima. Terjemahan oleh Jeanette Murad. Erlangga: Jakarta.

12. Erlangga John J. Macionis. (2008). Society the basics. United States of America: Prentice Hall.

13. Fausiah, Fitri., \& Widury, Julianti. (2007). Psikologi Abnormal Klinis Dewasa. Jakarta: UI-PRESS.

14. Gesti Lestari. (2012). Fenomena Homoseksual di kota Yogyakarta. Skripsi S1. Universitas Negeri Yogyakarta.

15. Halgin, R. P., \& Withbourne, S. K. (2010). Psikologi abnormal: Perspektif klinis pada gangguan psikologis. Jakarta: Salemba Humanika

16. Hanifa Kartika Pertiwi. (2011). Fenomena Perilaku Seksual waria. Skripsi S1 Universitas Negeri Yogyakarta.

17. Haryanta, Agung Tri \& Sujatmiko. (2012). Kamus Sosiologi. Surakarta: Aksara Sinergi Media.

18. Haryanto, Sindung. (2012). Spektrum Teori Sosial Dari Klasik Hingga Posmodern. Yogyakarta: AR-Ruzz Media.

19. Herdiansyah, H. (2010). Metodologi penelitian kualitatif: Untuk ilmu-ilmu sosial. Jakarta: Salemba Humanika.

20. Herdiansyah, Haris. (2010). Metodologi Penelitian Kualitatif untuk Ilmu-ilmu Sosial. Jakarta : Salemba Humanika

21. Homoseks, (2016) Pekerja Seks, dan Seks Bebas di Indonesia. Yogyakarta: INSISTPress. 
22. https://media.neliti.com/media/publicatio ns/932-ID-kaum-lesbian-di-kota-।

23. Irawan, A, A. (2015). Aku Adalah Gay (Motif yang Melatar Belakangi Pilihan Menjadi Gay). Jurnal Bimbingan dan Konseling 4, (1), 1-11.

24. Journal of Homosexuality.

25. Kali, Amply. (2013). Diskursus Seksualitas Michel Foucault. Flores: Ledalero.

26. Kartono, K. (2006). Psikologi wanita 1: Mengenal gadis remaja dan wanita dewasa. Bandung: Mandar Maju.

27. Kartono, Kartini. (2011). Patologi Sosial. Jakarta: PT RajaGrafindo Persada Kartono.

28. Kartini. (1989). Psikologi Abnormal dan Abnormalitas Seksual. Keberagaman Orientasi Seksual Manusia. Yogyakarta: Perkumpulan Keluarga Berencana Indonesia (PKBI) DIY.

29. Kusuma, D, A. (2014). Pembentukan Perilaku Seksual pada Pasangan Lesbi dan Gay di Yogyakarta Skripsi tidak diterbitkan. Universitas Negeri Yogyakarta.

30. Maliki, Zainuddin. (2012). Rekonstruksi Teori Sosial Modern. Yogyakarta: Gajah Mada University Press.manado.pdf

31. Maslim, R (2013). Diagnosis Gangguan Jiwa Rujukan Ringkas dari PPDGJ III dan DSM-5. Jakarta : PT Nuh Jaya

32. Miles, Matthew B., \& Huberman, A. Michael. (2009). Analisis Data Kualitatif. Jakarta: UI-PRESS.Moleong, Lexy J. (2007). Metodologi Penelitian Kualitatif. Bandung: PT Remaja Rosda Karya.

33. Mu'allafah, S. (2012). Dinamika kepribadian perempuan biseksual: Studi kasus pada seorang perempuan biseksual yang mengalami pelecehan seksual. (Skripsi). Malang: Program sarjana Universitas Negeri Malang.

34. Nevid,.Rathus \& Greene.(2003). Psikologi Abnormal. Jakarta: Penerbit Erlangga. Pontotoring, M., (2012), KaumLesbian di Manado, New York: Oxford University Press.

35. Nurkholis. (2013). Faktor-faktor yang melatarbelakangi lesbian dan kondisi psikologisnya. Jurnal Online Psikologi, 01 (01), 174-186.
36. Nurmala, D., Anam, C., \& Suyono, H. (2006). Studi kasus perempuan lesbian (Butchy) di Yogyakarta. Indonesian Psychological Journal, 3 (1), 28 - 37. Nevid, J. S., Rathus, S. A., \& Greene, B. (2005). Psikologi abnormal jilid 2

37. Okdinata. (2009). Religiusitas kaum homoseks (Studi kasus tentang dinamika psikologis keberagaman gay muslim di Yogyakarta). Yogyakarta: Universitas Islam Negeri Sunan Kalijaga Yogyakarta.

38. Okdinata. (2009). Religiusitas Kaum Homoseks: Studi Kasus Tentang Dinamika Psikologis Keberadaan Gay Muslim Di Yogyakarta. Skripsi S1. Universitas Islam Negeri Sunan Kalijaga Yogyakarta.

39. Oxford Dictionary. (2003). Oxford Learner's Pocket Dictionary New Edition.

40. Person's Self Compassion. Journal of Gay \& Lesbi Social Service. 27 (2), 172186

41. Puspita, Mertania. (2010). Fenomena Butch Dalam Teori Peran. Skripsi S1.

42. Rachmawati. (2011). Berbagi Suami: Menjadi Istri Gay. Skripsi S2.

43. Raharjo, Trubus. (2003). Hubungan Fantasi Seksual dan Lama Tinggal Terhadap Kecenderungan Perilaku Homoseksual Pada Siswa di Lingkungan Pergaulan yang Homogen di Pesantren. Skripsi S2. Yogyakarta: Universitas Gajah Mada.

44. Rangkuti, R.Y. (2012). Homoseksual dalam perspektif hukum Islam. Jurnal Ilmu Syari'ah dan Hukum, 4 (I).

45. Ratna, Nyoman Kutha. (2010). Metodologi Penelitian Kajian Budaya dan Ilmu Sosial Humaniora Pada Umumnya. Yogyakarta: Pustaka Pelajar.

46. Rohmi, H. (2007). Sruktur kepribadian dalam perspektif psikoanalisa: Studi kasus pada lesbian. Malang: Universitas Islam Negeri Malang.

47. Sadena Febriana Suryatiningsih. (2013). Pembagian Peran Pada Pasangan Orientasi Seksual Sejenis yang Memiliki Komitmen Marriage-Like (Studi Eksploratif Terhadap Satu Pasangan Gay di Kota Bandung). Skripsi S1. Universitas Pendidikan Indonesia. 
48. Sarwono, Sarlito Wirawan. Hubungan Lesbian pada remaja. Semarang: Universitas Katolik Soegijapranata.

49. Siahaan, Jokie MS. (2009). Perilaku Menyimpang: Pendekatan Sosiologis.

50. Singgih, D, S \& Singgih, D, S. 2007. Psikologi Remaja. Jakarta: Penerbit Gunung Mulia.

51. Sinta Arum Setya P. (2013). Fenomena Komunitas Kaum Lesbi di Kota Klaten. Skripsi S1. Universitas Negeri Yogyakarta.

52. Soekamto, Soerjono. (1990). Sosiologi Suatu Pengantar. Jakarta: PT Grafindo Persada.

53. Soetjiningsih. (2004). Tumbuh Kembang Remaja dan Permasalahannya. Jakarta: CV Sagung Seto.

54. Soetomo. (2008). Masalah Sosial dan Upaya Pemecahannya. Yogyakarta: Pustaka Pelajar.

55. Spencer, Colin. (2011). Sejarah Homoseksualitas: dari Zaman Kuno Hingga Sekarang. Bantul: Kreasi Wacana.

56. Stewart, C. J., \& Cash, W. B. (2012). Interviuw: Prinsip dan praktik. Jakarta: Salemba Humanika.

57. Sugiyono. (2013). Memahami Penelitian Kualitatif. Bandung: Alfabeta. Utama, Lingga Tri. (2013). Seksualitas Rasa Rainbow Cake: Memahami

58. Suharnan. (2005). Psikologi Kognitif. Surabaya : Srikandi

59. Sumadi, N., Suriadi., \& Kirana, W. (2013). Pengalaman traumatik dan komunikasi keluarga tidak efektif dalam pembentukan pribadi penyimpangan seksual lesbian. Jurnal keperawatan, 01 (01). 
